\title{
Wanita Haid dengan Metode Syarah Perspektif Teologi Islam
}

\author{
Siti Rahmah \\ Jurusan Ilmu Hadis, Fakultas Ushuluddin, \\ UIN Sunan Gunung Djati Bandung \\ strhmaah@gmail.com
}

\begin{abstract}
This study aims to discuss the sharah about the hadith of menstruating women from a theological perspective. This research is a qualitative type through literature study with the method of sharah and theological analysis. The results and discussion of this study include the meaning of menstruation, syarah about the hadith of menstruating women, and the problems of menstruating women with theological perspective. This research concludes that theologically menstruating women according to the hadith sharah can still maintain a relationship with Allah through practices such as charity, doing good deeds, reciting the Qur'an, praying, doing istighfar, and reciting zikr. This study recommends especially for Islamic religious extension workers to be able to provide understanding to Muslim audiences about the sharah about the hadith of menstruating women from a theological perspective.
\end{abstract}

Keywords: Hadith; Menstruation; Syarah; Theology.

\begin{abstract}
Abstrak
Penelitian ini bertujuan untuk membahas syarah tentang hadis wanita haid dalam perspektif teologi. Penelitian ini merupakan jenis kualitatif melalui studi pustaka dengan metode syarah dan analisis teologis. Hasil dan pembahasan penelitian ini mencakup makna haid, syarah tentang hadis wanita haid, dan problema wanita haid perspektif teologi. Penelitian ini menyimpulkan bahwa secara teologis wanita haid menurut syarah hadis tetap dapat menjalin keterhubungan dengan Allah melalui amalan-amalan seperti bersedekah, beramal kebajikan, mengulang hafalan AlQur'an, berdoa, istighfar, dan berzikir. Penelitian ini merekomendasikan terutama bagi para penyuluh keagamaan Islam untuk dapat memberikan pemahaman kepada khalayak umat muslim mengenai syarah tentang hadis wanita haid dari perspektif teologi.
\end{abstract}


Kata kunci: Hadis, Haid, Syarah, Teologi.

\section{Pendahuluan}

Salah satu problema yang dilekatkan pada seorang wanita adalah haid (Rahmatullah, 2013). Haid dan wanita adalah dua hal yang tidak bisa dipisahkan (Widad, 2017). Setiap wanita dipastikan akan mengalaminya karena darah haid merupakan sifat alamiyah setiap wanita (Widad, 2017) yang diberikan Allah Swt (Rahmatullah, 2013). Di masa lalu, tak sedikit masyarakat menganggap bahwa haid yang dialami para wanita itu adalah sebuah kutukan (Tanahitumesseng, Ratnawati, \& Cholil, 2017) dan menganggapnya sebagai hal yang tabu (Umar, 2007). Dalam kondisi itu, wanita harus menerima dengan pasrah menjadi tertuduh sebagai orang yang membawa malapetaka yang tidak diinginkan (Suhendra, 2014). Padahal, haid mempunyai makna teologis yang amat penting (Umar, 2007).

Penelitian terdahulu telah dilakukan dengan baik oleh para peneliti. Antara lain penelitian yang dilakukan oleh Ahmad Suhendra (2014), dengan judul "Haid (Menstruasi) dalam Hadis." Pembahasan penelitian ini terdapat ulasan umum tentang haid, dalil haid serta pemahaman historis tentang haid. Artikel ini menyimpulkan bahwa haid sama sekali tidak menjadi alat untuk menistakan perempuan, dan adanya pelarangan melaksanaan ibadah tertentu bagi perempuan yang sedang haid itu adalah salah satu bentuk keringanan yang diberikan agama kepada perempuan demi kemaslahatan. Ada pula penelitian yang dilakukan oleh Umar (2007), dengan judul "Teologi Menstruasi Antara Mitologi dan Kitab Suci." Pembahasan penelitian ini yaitu haid ternyata bukan hanya sebagai fungsi biologis fisik semata dari tubuh seorang wanita. Namun menurut sebagian besar masyarakat tradisional, haid ini sangat eksklusif yang dianggap sebagai simbol yang menandakan makna dan mitos tertentu (Umar, 2007). Artikel ini menyimpulkan bahwa meskipun haid tabu tidak lagi populer, tetapi akibat yang ditimbulkan masih tetap berakar dalam masyarakat. Jika konsep haid yang umumnya dinilai kaum feminis banyak merugikan kaum wanita sulit dihilangkan, maka alternatifnya adalah mengeliminasi dampak negatif yang ditimbulkannya dengan melakukan reinterpretasi terhadap teks. Penelitian ini merekomendasikan perlu dilakukannya reidentifikasi terhadap teks, apakah teks itu mengungkapkan simbol, atau makna, atau kedua-duanya (Umar, 2007).

Kerangka berpikir penelitian ini disusun berdasarkan hasil-hasil penelitian terdahulu untuk mendukung temuan sebelumnya. Kerangka berpikir penelitian ini memandang perlu menegaskan kembali tentang penjelasan haid. Haid merupakan siklus biologis-kodrati yang dialami perempuan dalam kelangsungan kesehatan reproduksi perempuan (Rahmatullah, 2013). Persoalan haid yang dialami wanita dengan doktrin 
agama dianggap sebagai kondisi yang menempatkan perempuan rentan dengan mitos-mitos yang menyudutkannya (Umar, 2014). Haid dalam lintasan sejarah dianggap sebagai simbol yang sarat dengan makna dan mitos (Umar, 2014). Asal-usul serta makna penamaan haid sendiri ternyata mempunyai makna mistis (Umar, 2001). Konon, wanita yang sedang dalam masa haid akan lebih mudah didekati oleh makluk halus. Aroma darah saat haid, disukai mereka dan mengundang mereka untuk mendekati (Mistis, 2015). Seorang wanita yang sedang haid tidak dapat melakukan shalat, puasa, dan membaca Al-Qur'an (Rachman, 2008). Larangan-larangan tersebut sesuai dengan hadis-hadis Rasulullah Saw (Sumaji, 2008). Itu semua merupakan rukhshah atau keringanan dalam menjalankan ibadah (Hendrik, 2006). Namun hal tersebut bukan berarti pintu-pintu ibadah lainnya tertutup dan tidak dapat dilakukan (Rachman, 2008). Daripada itu, penjalasan (syarah) hadis tentang haid dari sudut pandang fiqih tidak cukup dibutuhkan pemahaman dari perspektif lain yakni teologi. Ditegaskan bahwa haid mempunyai makna teologis yang amat penting (Umar, 2007). Ia bukanlah peristiwa fisik biologis semata, melainkan mengandung konsep dan makna teologis (Umar, 2007).

Berdasarkan paparan di atas, penelitian ini berusaha menyusun formula penelitian (Darmalaksana, 2020), yaitu rumusan masalah atau hipotesis, pertanyaan penelitian, dan tujuan penelitian. Rumusan masalah atau hipotesis penelitian ini adalah terdapat syarah tentang hadis wanita haid dalam perspektif teologis. Pertanyaan penelitian ini secara terperinci, yakni bagaimana makna haid, bagaimana syarah tentang hadis wanita haid, dan terakhir bagaimana problem wanita haid perspektif teologi. Penelitian ini bertujuan untuk membahas syarah tentang hadis wanita haid perspektif teologis. Penelitian ini diharapkan dapat memberikan manfaat dan kegunaan khususnya bagi pengayaan khazanah pengetahuan Islam.

\section{Metode Penelitian}

Penelitian ini merupakan jenis kualitatif dengan menerapkan studi pustaka (Darmalaksana, 2020). Penelitian dilaksanakan dengan menghimpun sumber-sumber kepustakaan, baik primer maupun sekunder. Setelah terhimpun, sumber-sumber kepustakaan dikategorikan sesuai pertanyaan penelitian (Darmalaksana, 2020). Data sumber kepustakaan yang telah dikategorisasi kemudian ditampilkan sebagai temuan penelitian (Rahmah \& Darmalaksana, 2020). Selanjutnya, data tersebut diabstraksikan secara apa adanya sehingga terbentuk menjadi fakta penelitian. Penulis melakukan interpretasi terhadap fakta penelitian tersebut untuk menghasilkan informasi atau pengetahuan. Penelitian ini menerapkan metode syarah hadis (Darmalaksana, 2020) melalui interpretasi dengan analisis teologis. 


\section{Hasil Penelitian dan Pembahasan}

\section{Makna Haid}

Haid memiliki ragam pengertian (Widad, 2017). Menurut bahasa, kata haid berasal dari bahasa Arab (Rahmatullah, 2013) yang merupakan mashdar dari fi'il khaada-yahidu-khaidon (Fi'ismatillah, 2019). Dalam kamus Maqoyisul Lughoh disebutkan bahwa khaada artinya adalah mengeluarkan air yang berwarna merah (Fi'ismatillah, 2019). Para ulama menyebutnya asSailin (Mujib \& Ulfah, 1994) yang berarti mengalir (Sabiq, 1993). Dalam hal ini, yang dimaksud adalah darah yang keluar dari vagina pada saat dalam kondisi normal, bukan karena melahirkan atau pecahnya keperawanan (Sabiq, 2017). Sedangkan menurut istilah, haid yaitu aliran darah yang keluar dari ujung rahim wanita dalam keadaan sehat tanpa sebab melahirkan atau dalam keadaan sakit, dan keluarnya dalam batas waktu tertentu (Mujib \& Ulfah, 1994) yang telah diketahui atau kebiasaan (Syah, 2017).

Dalam lintasan sejarah, haid dianggap sebagai simbol yang sarat dengan makna dan mitos. Darahnya sendiri dianggap sebagai tabu (Umar, 2007). Makna darah haid sering dikaitkan dengan sakit, kematian, kehilangan kendali, emosi, atau peperangan yang menunjuk pada sakit atau tidak berfungsinya tubuh (Abdullah, 2002). Hampir setiap suku, bangsa, agama, dan kepercayaan, mempunyai konsep perlakuan khusus terhadapnya (Umar, 2007). Secara historis haid terkait dengan perkembangan peradaban yang dipengaruhi oleh teks dan doktrin yang telah diinterprestasikan dan reinterprestasi dari generasi satu ke generasi yang lain, yang tampak begitu sulit untuk berubah. Secara kultural, menstruasi mengalami proses pemaknaan yang kontekstual dengan seting sosial tertentu yang bersifat fungsional bagi penataan sosial (Abdullah, 2002).

Dikisahkan bahwa haid muncul sejak adanya wanita pertama kali, yaitu Hawa (Syah, 2017). Bersamaan dengan terjadinya peristiwa dosa asal yang diakibatkan dari rayuan Hawa untuk memakan buah terlarang (Umar, 2007). Ketika Hawa mengambil buah terlarang di surga. Getah buah tersebut mengotori Hawa yang bersamaan dengan turunnya murka Allah dan keluarlah darah tersebut dari farjinya. Hal tersebut berjalan rutin hingga sampai anak cucunya (Syah, 2017). Oleh karena itu, haid memberikan citra negatif kepada kaum wanita karena dianggap bahwa Hawa menjadi penyebab tergelincirnya Adam dari surga ke planet bumi (Dahri, 2012). Selain itu haid juga diyakini sebagai bagian dari kutukan tuhan terhadap kesalahan Hawa. Karena itu, wanita yang sedang menjalani masa haid mendapatkan perlakuan khusus, termasuk dikucilkan masyarakat, bahkan dari lingkungan keluarganya sendiri. Karena wanita 
haid dikelilingi oleh darah terlarang dan sebagian hidupnya harus dihabiskan di pengasingan (Umar, 2007).

Haid memainkan peranan penting dalam perkembangbiakan manusia. Secara biologis, haid atau menstruasi merupakan siklus reproduksi yang menandai sehat dan berfungsinya organ-organ reproduksi perempuan (Dahri, 2012). Rahim menyiapkan diri untuk mendapatkan kehamilan dengan jalan mempertebal saluran dalamnya, yang dinamakan endometrium. Sekali dalam sebulan, sel telur dilepaskan dari salah satu indung telur, organ kecil yang berada pada kedua sisi rahim. Sel telur tersebut, yang dinamakan ovum, menuruni tuba fallopi menuju rahim. Jika sel telur tersebut dibuahi oleh sel sperma, ia akan tinggal pada saluran bagian dalam rahim (Rachman, 2010). Haid merupakan titik awal dari tanda seorang remaja perempuan beranjak dewasa (Rahmatullah, 2013). Haid ialah darah yang keluar dari rahim dinding seorang wanita apabila telah menginjak usia baligh dan wanita menjalaninya pada waktuwaktu tertentu pada setiap bulan (Al-Jazairi, 2017). Waktu permulaan keluarnya haid menurut para ulama dimulai pada usia 9 tahun (dengan hitungan tahun Qamariah, 1 tahun sama dengan 354 hari). Biasanya haid terjadi pada usia 10-13 tahun. Namun, karena pengaruh berbagai faktor, seperti gizi dan lingkungan sosial, usia menarche atau haid pertama bisa terjadi lebih cepat (Azzam, 2012). Jika darah keluar sebelum usia tersebut maka dianggap darah penyakit, bukan darah haid. Haid terjadi adakalanya sehari semalam, ini merupakan masa paling pendek (Ahmad al-Ghozy, 2013). Lamanya masa haid umumnya sekitar 2-7 hari (Azzam, 2012). Sedangkan batasan maksimal haid tidak ditentukan. Jadi apabila wanita tua melihat darah keluar maka darah tersebut adalah darah haid (Ayanih, 2010). Sebagian besar ulama berpendapat, haid tidak terjadi di bawah umur sembilan tahun. Jika seorang perempuan mengeluarkan darah sebelum umur sembilan tahun, maka itu bukanlah darah haid, melainkan darah penyakit atau darah yang rusak (fasad). Masa keluarnya darah haid bisa jadi seumur hidup. Tidak ada dalil bahwa haid akan berhenti pada masa tertentu (Sabiq, 2017).

Dalam tradisi bangsa Indonesia, haid sering diistilahkan dengan datang bulan, sedang kotor, kedatangan tamu, bendera berkibar dan sebagainya. Istilah-istilah seperti ini juga dikenal di belahan bumi lain. Istilah-istilah tersebut masing-masing mempunyai filosofi sendiri yang berujung pada kesimpulan bahwa haid bukanlah peristiwa fisik biologis semata, melainkan mengandung konsep dan makna teologis (Umar, 2007).

\section{Syarh Hadis tentang Wanita Haid}

Ada beberapa larangan bagi wanita haid, di antaranya yaitu shalat, puasa, jima', thawaf, dan membaca al-Qur'an (Mianoki, et al., 2014). Namun salah satu yang menjadi penelitian ulama yaitu hadis yang melarang 
wanita yang sedang haid untuk membaca Al-Qur'an (Nasution, 2015) dengan lisannya (Asy-Syarif, 2006). Seperti di dalam kitab Maktabatu alMa'arif Riyadh Nomor 131 kitab Bersuci, Bab Orang junub dan wanita haid tidak boleh membaca Al-Qur'an. Adapun hadis yang dimaksud sebagai berikut:

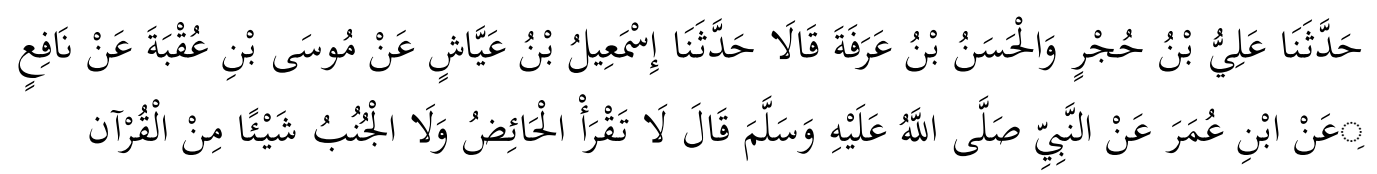

Telah menceritakan kepada kami Ali bin Hujr dan Al-Hasan bin Arafah keduanya berkata; telah bercerita kepada kami bahwa Isma'il bin Ayyasy dari Musa bin Uqbah dari Nafi' dari Ibnu Umar dari Nabi Saw, beliau bersabda, "Wanita haid dan orang yang junub tidak boleh membaca sesuatu pun dari Al-Qur'an (Ensiklopedia Hadis).

Hadis riwayat Imam at-Tirmizi diawali oleh at-Tirmidzi dengan haddasana dalam mengemukakan riwayat itu, Imam at-Tirmidzi menyandarkan riwayatnya kepada Ali bin Hujr dan al-Hasan bin Arafah. Dengan itu, maka Ali bin Hujr dan al-Hasan bin Arafah disebut sebagai sanad pertama dan Ibnu Umar sebagai periwayat pertama. Karena dia termasuk sahabat Nabi yang berstatus sebagai pihak pertama yang menyampaikan riwayat hadis tersebut. Lambang periwayatan yang diucapkan oleh Imam at-Tirmizi dari jalur Ali bin Hujr dan al-Hasan bin Arafah adalah haddasana. Itu berarti, metode periwayatan yang digunakan adalah as-Sama. Begitu juga dengan Ismail bin Ayyash dan Musa bin Uqbah adalah haddasana. Nafi dan Ibnu Umar adalah 'an, hadis ini berarti tergolong sebagai hadis mu'an'an. Namun, periwayatan Nafi dari Umar adalah silsilah zahabiyah (yang dijamin kesinambungannya), sehingga metode periwayatannya bisa digolongkan menggunakan as-Sama. Sanad hadis ini adalah daif al-Isnad karena terdapat rawi-rawi yang dinilai daif. Dimana Ismail bin Ayyash sebagai periwayat ke IV dan urutan sanad ke II dinilai daif sebab meriwayatkan hadis selain dari sahabat Syam. Karena bila dilihat dari jalur riwayatnya adalah dari gurunya Musa bin Uqbah yang kesehariannya berdomisili di Madinah yaitu bagian negeri Hijaz, sedangkan Ismail bin Ayyash berada di Syam. Sehingga periwayatan selain dari kalangan Syam ditolak. Sedangkan rawi yang dinilai daif selain Ismail bin Ayyash adalah al-Hasan bin Arafah sebagai periwayat ke V dan urutan sanad ke I yang dinilai Șaduq laisa bil kazab dan la ba'sa bihi yang lafaz-lafaz tersebut tidak menunjukkan kedabitan (Khotimah, 2016).

Dalam masalah ini, para ulama berbeda pendapat (Awwam, 2017). Namun secara garis besar ada dua pendapat. Ada yang memperbolehkan dan ada juga yang tidak memperbolehkan (Al-Majidi, 2008). Dalam 
mazhab Malikiyah (Arifin, 2017). Atau yang dikenal dengan nama Imam Malik berpendapat bahwa diperbolehkan bagi wanita haid membaca AlQur'an (KTB, 2013). Begitu pun dengan pendapat Ibnu Hazm yang membolehkan membaca al-Qur'an secara mutlak (Sarwat, 2019). Sedangkan menurut Ath-Thahawi diperbolehkan bagi wanita yang sedang haid membaca Al-Qur'an namun kurang dari satu ayat, seperti yang dikutipkan dalam Syarah Al-Kanzu dari kitabnya mazhab Hanafi (KTB, 2013). Al-Awza'i mengatakan, Imam Az-Zuri ditanya tentang wanita yang junub, nifas, dan haid. Az-Zuhri berkata, "Tidak ada dispensasi bagi mereka untuk membaca Al-Qur'an sedikit pun (Al-Majidi, 2008).

Sedangkan sebagian ulama berpendapat bahwasannya wanita haid tidak boleh menyentuh Al-Qur'an dan juga tidak boleh membacanya (AlMajidi, 2008). Seperti ulama mazhab Syafi'i termasuk Sufyan Ats-Tsauri, Ibn Mubarak dan Ahmad berpendapat bahwa wanita haid dilarang membaca apapun dari ayat al-Qur'an kecuali sekedar bacaan tasbih dan tahlil (zikir) (Elfia, 2019). Namun dalam masalah ini para ulama empat madzhab sepakat atas bolehnya membaca Al-Qur'an bagi orang yang berhadats, baik hadats besar maupun kecil selama tidak menyentuhnya (Albantany, 2014). Karena menurut Ibnu Taimiyah dalam Al-Fatwa Majmuah Ibnu Qasim, larangan tersebut sebenarnya tidak berdasarkan sunah karena sabda beliau, "wanita haid dan orang junub tidak boleh membaca Al-Qur'an", adalah hadis lemah (Sa'di, 2006). Dan juga menurutnya membaca Al-Qur'an adalah perbuatan baik dan berpahala (Sarwat, 2019). Namun perlu diingat bahwa pendapat mayoritas ulama mengharuskan seorang wanita untuk tetap menghormati mushaf Al-Qur'an (Rachman, 2008).

\section{Wanita Haid Perspektif Teologi}

Menstruasi atau haid tidak hanya merupakan masalah biologis yang secara rutin dialami kaum wanita, tetapi juga mempunyai makna teologis yang amat penting (Umar, 2007). Haid yang dialami wanita dianggap sebagai kutukan Tuhan (Tanahitumesseng, Ratnawati, \& Cholil, 2017). Karena itu perempuan yang sedang mengalami haid dianggap sedang berada dalam suasana tabu dan darah menstruasinya dianggap sebagai darah tabu yang menuntut perlakuan khusus (Yuswati, 2007). Tabu haid menurut Freud merupakan cerminan dari sikap masyarakat yang ambivalen terhadap wanita seperti wanita dianggap kotor dan terkena kekuatan jahat sehingga perlu dijauhi (Abdullah, 2002). Istilah tabu pada darah haid berasal dari rumpun bahasa Polynesia. Kata ta berarti tanda, simbol dan kata bu adalah keterangan tambahan yang menggambarkan kehebatan, lalu diartikan sebagi tanda yang ampuh (Yuswati, 2007). Kepercayaan tentang roh jahat yang dibawa oleh perempuan menjadi suatu keyakinan tentang sifat buruk dari haid dan wanita yang mengalaminya 
(Abdullah, 2002). Haid bukan hanya sebagai siklus secara fisik yang membedakan dengan nyata antara wanita dan pria, namun dimaknai dengan segala pantangan dan larangan serta ancaman yang membahayakan (Yuswati, 2007).

Pada umumnya, wanita yang sedang haid mengetahui laranganlarangan ibadah. Karenanya, banyak di antara mereka yang tidak melakukan apa pun kecuali hanya sekedar mengisi kekosongan waktu (Musyafa'ah, 2018). Meskipun seorang wanita yang sedang haid terhalang untuk melakukan ibadah-ibadah tertentu, bukan berati ia buruk, lemah, atau tidak sempurna imannya. Wanita mana pun yang ketika haid ia mensyukurinya, dengan tetap melanggengkan ibadah lain yang tidak diharamkan baginya, niscaya ia layak menghuni surga (Azzam, 2012). Sebenarnya ketika haid datang, seorang wanita dapat melakukan aktivitas ibadah, sehingga tidak ada waktu yang terbuang untuk selalu dekat kepada Allah SWT. Sekalipun dalam kondisi haid, seorang perempuan boleh melakukan amal kebaikan dan beramal shalih. Haid tidak menghalangi seseorang untuk beribadah kepada Allah. Adanya larangan terhadap ibadah tertentu, bukan berarti perempuan dianggap najis, tapi justru merupakan rahmat dan bentuk kasih sayang Allah SWT terhadap kaum wanita (Musyafa'ah, 2018).

Masalah haid dijelaskan di dalam QS. Al-Baqarah ayat 222: Mereka bertanya kepadamu (Muhammad) tentang haid. Katakanlah, "Haid itu adalah sesuatu yang kotor." Karena itu jauhilah istri pada waktu haid, dan jangan kamu dekati mereka sebelum mereka suci. Apabila mereka telah suci, campurilah mereka sesuai dengan (ketentuan) yang diperintahkan Allah kepadamu. Sungguh, Allah menyukai orang yang tobat dan menyukai orang yang mengucilkan diri. Sebab turunnya ayat ini dijelaskan bahwa hadis riwayat Imam Ahmad dari Anas. Dalam hadis tersebut diceritakan bahwa bilamana wanita Yahudi sedang haid, masakannya tidak dimakan dan tidak boleh berkumpul bersama keluarga di rumahnya (Rahayu, 2012). Salah seorang sahabat menanyakan hal itu kepada Nabi, kemudian Nabi berdiam sementara maka turunlah ayat tersebut. Setelah ayat itu turun, Rasulullah Saw bersabda "Lakukanlah segala sesuatu (kepada isteri yang sedang haid) kecuali bersetubuh." Pernyataan Rasulullah ini sampai kepada orang-orang Yahudi, lalu orang-orang Yahudi dan matan penganut Yahudi seperti shock mendengarkan pernyataan tersebut. Apa yang selama ini diangap tabu tiba-tiba dianggap sebagai "hal yang alami." Kalangan mereka bereaksi dengan mengatakan apa yang disampaikan oleh laki-laki itu (Rasulullah) adalah suatu penyimpangan dari tradisi besar mereka. Usaid bin Hudhair dan Ubbad ibn Basyr melaporkan reaksi tersebut kepada Rasulullah, lalu wajah Rasulullah berubah karena merasa kurang enak terhadap reaksi tersebut (Umar, 2001). Dan kami (Usayd ibn Hudayr dan Ubbad bin Basyr) mengira beliau marah kepada mereka berdua. Mereka berdua langsung keluar 
(sebelumnya) beliau menerima air susu hadiah dari mereka dan memberi mereka minum susu, sehingga mereka berdua tahu bahwa Rasulullah tidak marah kepada mereka (Katsir, 1986).

Banyak amalan yang bisa dikerjakan oleh kaum wanita saat mereka haid (Rosana, 2015). Beberapa amalan tersebut di antaranya bersedekah (Akhirat, 2015) beramal kebajikan, mengulang hafalan Al-Qur`an, berdoa, istighfar (Sinaga, 2017) dan berzikir (Nora, 2020). Rasulullah Saw bersabda (Rosana, 2015):

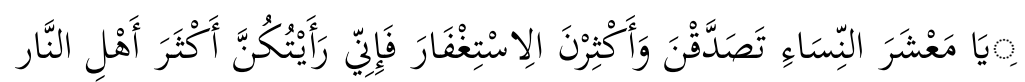

Wahai kaum wanita! Bersedekahlah kamu dan perbanyakkanlah istighfar. Karena, aku melihat kaum wanitalah yang paling banyak menjadi penghuni Neraka (HR. Muslim).

Darah haid adalah unsur penting dalam penciptaan dan kehidupan manusia. Tidak heran bila sekarang muncul teologi darah yang membahas dari mana asal usul darah? Kapan darah itu muncul dan mengalir ke dalam tubuh? Bagaimana masuknya darah ke dalam tubuh? Bagaimana pula asalusul darah haid? (Umar, 2014). Dalam Islam sendiri banyak sekali hadis yang menjelaskan tentang haid, baik interaksi Nabi Saw dengan istri-istri beliau yang sedang menstruasi maupun masalah hukum yang berkaitan dengan haid (Suhendra, 2014). Ulama fikih menyatakan bahwa ada beberapa amalan yang terlarang dilakukan perempuan ketika haid (Duhriah, 2015). Selain itu, ada juga beberapa aturan yang berlaku di beberapa masyarakat tertentu, wanita yang sedang haid dilarang memotong kuku, memotong dan membasahi rambut, dilarang menggunakan kosmetik maupun aksesoris lainnya. Padahal hal itu tidak terdapat dalam teks-teks agama, baik Al-Qur'an maupun hadis (Rahmatullah, 2013). Banyak persepsi keliru yang berkembang selama ini, bahwa seorang perempuan yang tengah haid tidak boleh beribadah sama sekali. Alhasil, banyak sekali perempuan yang merasa bebas dengan keadaan tersebut meski dengan diiringi sifat sensitive disebabkan haid (Rachman, 2008).

\section{Kesimpulan}

Setiap wanita dewasa pasti merasakan haid. Karena suatu hal yang yang fitrah yang ada di dalam dirinya. Perihal haid tentu terdapat banyak hadis yang mengaturnya, seperti hal-hal yang tidak boleh dilakukan oleh wanita haid serta apa saja yang dapat dilakukan oleh wanita haid dalam mendekatkan diri kepada Allah. Secara teologis, wanita haid menurut syarah hadis tetap dapat menjalin keterhubungan dengan Allah melalui 
amalan-amalan seperti bersedekah, beramal kebajikan, mengulang hafalan Al-Qur`an, berdoa, istighfar dan berzikir. Penelitian ini diharapkan memiliki implikasi manfaat sebagai khazanah pengetahuan bagi khalayak umat muslim. Penelitian ini disadari memiliki keterbatasan khususnya dalam penyajian hadis yang berkaitan tentang haid dan syarah mengenai hadis tersebut melalui perspektif teologis sehingga dibutuhkan penelitian lebih lanjut secara lebih komprehensif, integral, dan mendalam. Penelitian ini merekomendasikan terutama bagi para penyuluh keagamaan Islam untuk dapat memberikan pemahaman kepada khalayak umat muslim mengenai syarah tentang hadis wanita haid dari perspektif teologi.

\section{Referensi}

Abdullah, I. (2002). Mitos Mentruasi: konstruksi Budaya atas Realitas Gender. Humaniora, 36.

Ahmad al-Ghozy, U. (2013). Ketika Cewek Datang Bulan: Panduan Praktis $\mathcal{E}$ Islami Buat Cewek Saat Haid. Jakarta: Gen Mirqat.

Akhirat, N. (2015). Kun Anta: Cantik dari Hati Cantik Jadi Diri Sendiri. Wahyu Qolbu.

Albantany, N. '. (2014). Pahala dan Doa Wanita Ketika Datang Bulan . Jakarta: Lembar Langit Indonesia.

Al-Jazairi, A. B. (2017). Ensiklopedia Muslim. Jakarta: Daarul Falah.

Al-Majidi, A. M. (2008). Bagaimana Rasulullah Mengajarkan al-Qur'an Kepada para Sahabat? (Zulfikar, Ed., \& A. K. Seff, Trans.) Jakarta: Darul falah.

Arifin, N. (2017). Rindu di Penghujung Doa. Lampung: Perahu Litera.

Asy-Syarif, I. b. (2006). syarah Kumpulan Hadits Shahih Tentang Wanita. Jakarta: Pustaka Azzam.

Awwam, Q. (2017). Fiqih Wanita Panduan Hidup Wanita dalam Perspektif Islam. Jakarta: Cerdas Interaktif.

Ayanih, U. (2010). Dahsyatnya Shalat dan Doa Ibu. Jakarta: Raih Asa Sukses. Azzam, U. (2012). La Tahzan Untuk Wanita Haid. Jakarta: Qultum Media.

Dahri, N. (2012). Reproduksi Perempuan dalam Perspektif Islam (Tinjauan terhadap Haid, Nifas, dan Istihadhah). Marwah Jurnal Perempuan Agama dan Jender, 2.

Darmalaksana, W. (2020). Cara Menulis Proposal Penelitian. Bandung: Fakultas Ushuluddin UIN Sunan Gunung Djati Bandung.

Darmalaksana, W. (2020). Kelas Menulis dari Proposal ke Artikel Ilmiah, Publikasi Jurnal, dan Hak Kekayaan Intelektual. (W. Darmalaksana, Ed.) Bandung: Sentra Publikasi Indonesia.

Darmalaksana, W. (2020). Metode Penelitian Kualitatif Studi Pustaka dan Studi Lapangan. Pre-print Digital Library UIN Sunan Gunung Djati Bandung, 2.

Duhriah. (2015). Larangan Bagi Perempuan Haid Melakukan Aktifitas di Mesjid dan Membaca Al-Qur'an: Kajian Hadis Tematik. Jurnal Ilmiah 
Kajian Gender, 62.

Elfia. (2019). Kajian Tematis Tentang Larangan Perempuan Haid Masuk

Mesjid dan Membaca Al-Qur-an. Jurnal Analisis Gender dan Agama, 79.

Fi'ismatillah, R. (2019). Penafsiran Ayat-ayat haid dan Implikasinya Terhadap

Hukum (Studi Ali Asshobuni dalam Kitab Rawa'i Bayan). Salatiga: IAIN

Salatiga.

Hendrik, M. (2006). Problema Haid: Tinjauan Syari'at Islam dan Medis. Solo:

Tiga Serangkai.

Katsir, A. A.-F. (1986). Tafsir al-Qur'an al-Adzim. Beirut: Dar ar-Fikr.

Khotimah, A. (2016). Persepsi Santri Pondok Takhfidz di Semarang Terhadap

Hadis Tentang Larangan atau Diperbolehkannya Membaca Al-Qur'an Pada

Saat Haid. Semarang: UIN Walisongo.

KTB, P. i. (2013). Kumpulan Tanya Jawab Islam; Hasil Bahtsul Masail dan

Tanya Jawab Agama Islam. Indonesia: Daarul Hijrah Technology.

Mianoki, A., Bahren, R., Hafid, Hakim, m. S., Andriyani, A., Kartika, \&

Febriano, M. R. (2014). Majalah Kesehatan Muslim: Tetap Prima Saat

Haid Tiba. Yogyakarta: Pustaka Muslim.

Mistis, W. (2015). Penghuni Tanah Tabu. Jakarta: Bukune.

Mujib, A., \& Ulfah, M. (1994). Problema Wanita. Surabaya: Karya

Abditama.

Musyafa'ah, L. (2018). Hubungan Antara Religious Coping Dengan Nyeri

Saat Haid Pada Remaja. Universitas Islam Negeri Sultan Syarif Kasim.

Nasution, S. N. (2015). Studi Kualitas Sanad Hadis Membaca Al-Qur'an Bagi

Wanita Junub, Haid dan Nifas Tanpa Menyentuh Mushaf. Riau:

Universitas Islam Negeri Sultan Syarif Kasim.

Nora, E. (2020). Perempuan Kita Istimewa. Airiz Publishing.

Rachman, M. F. (2008). Haid Menghalangi Ibadah? No Way: Ibadah-ibadah

Utama Bagi Perempuan Haid. Bandung: Mizan Pustaka.

Rachman, M. F. (2010). Ibadah-ibadah saat Haid: Ketika Haid Tak Jadi

Halangan untuk Meraih Pahala. Bandung: Mizan Pustaka.

Rahayu, N. S. (2012). Studi Kritis Hadits Larangan dan Kebolehan

Perempuan Haid Memasuki Masjid. IAIN Walisongo.

Rahmah, S., \& Darmalaksana, W. (2020). Kontroversi Hadis Amalan

Sunnah Bulan Rajab. Khazanah Multidisiplin, 156.

Rahmatullah, L. (2013). Haid (Menstruasi) Dalam Tinjauan Hadis. Palastren, 24.

Rosana, H. M. (2015). Do'a dan Amalan Istimewa Ketika Datang Bulan.

Jakarta: Lembar Langit Indonesia.

Sabiq, S. (1993). Fiqih Sunnah. Bandung: Ma'rifat.

Sabiq, S. (2017). Fiqih Sunnah Jilid I. Jakarta: Republika Penerbit.

Sa'di, '. (2006). Fiqhun Nisa Thaharah-Shalat. Jakarta: Hikmah.

Sarwat, A. (2019). Hukum Menyentuh Mushaf dan Melafadzkan Al-Qur'an Bagi Wanita Haidh \& Berhadats. Lentera Islam. 
Sinaga, E. (2017). Manajemen Kesehatan Menstruasi. Jakarta: Iwwash. Suhendra, A. (2014). Haid (Menstruasi) dalam Hadis. Yogyakarta: UIN Sunan Kalijaga.

Sumaji, M. A. (2008). 125 Masalah Thaharah. Solo: Tiga Serangkai.

Syah, I. J. (2017). Mengenal Menstruasi dalam Prespektif Imam Syafi'i. Akademika, 51.

Tanahitumesseng, Y. E., Ratnawati, R., \& Cholil, M. (2017). Makna Menstruasi Bagi Perempuan Suku Naulu Dusun Rohua Kabupatrn Maluku Tengah Provinsi Maluku. Indonesian Journal of Women's Studies, 2.

Umar, N. (2001). Jurnal Dinamika Hak Asasi Manusia. Surabaya: Yayasan Obor Indonesia.

Umar, N. (2007). Teologi Menstruasi Antara Mitologi dan Kitab Suci. Jurnal Studi Gender dan Islam, 2.

Umar, N. (2007). Teologi Menstruasi: Antara Mitologi dan Kitab Suci . Jurnal paramadina, 2.

Umar, N. (2014). Ketika Fikih Membela Pembela Perempuan. Jakarta: Elex Media Komputindo.

Umar, N. (2014). Mendekati Tuhan dengan Kualitas Feminin. Jakarta: Elex Media Komputindo.

Widad, S. (2017). Konsepsi Saat Masa Menstruasi Berdasarkan Perspektif Fiqh dan Medis. Oksitosin Kebidanan, 16.

Yuswati. (2007). Dari Mitos Mestrual Taboo ke Dunia Kecantikan dan Fashion. UIN Sunan Kalijaga. 